Vitaliia Koibichuk,

Ph.D., Associate Professor, Sumy State University, Ukraine

DORCID ID, 0000-0002-3540-7922

e-mail:v.koibichuk@uabs.sumdu.edu.ua

Agnieszka Jakubowska,

Koszalin University of Technology, Poland

iD ORCID ID, 0000-0002-3610-8713

email: agnieszka.jakubowska@tu.koszalin.pl

Serhii Drozd,

Sumy State University, Ukraine

DORCID ID, 0000-0002-0716-3078

e-mail: henter8480@gmail.com

Anastasiia Sydorenko,

Sumy State University, Ukraine

e-mail: a.sydorenko@student.sumdu.edu.ua

Correspondence author: e-mail: henter8480@gmail.com

\title{
AN OVERVIEW OF THE ELEMENTAL AND FUNCTIONAL CONTENT OF THE HEALTH INDICATORS SYSTEM AS AN ECONOMIC CATEGORY
}

Abstract. This paper summarizes the arguments and counterarguments within the scientific discussion on defining the essence of health as an economic category. Systematization of the scientific works to defining health as an economic category requires a clear formation and a detailed description of the health determinants. For achieving the research goal, the study was carried out in the following logical sequence: 1) defining the general research problem; 2) theoretical analysis on the relevant publications; 3) classifying the health determinants by item functioning content; 4) defining areas of public policy concerning the investigated issue; 5) determining the global changes due to COVID-19 impact. The methodological base of this study was the methods of systematization, comparison, structural analysis, logical generalization, and bibliometric analysis. The study involved the VOSviewer 1.6.15 software in visualizing the obtained results. The study sample consists of 610 documents indexed in the Scopus database from 2010 to May 2021. The paper presents the classification of the health determinants by the item functioning content as follows: 1) medical and demographic orientation determinants; 2) morbidity determinants, their composition, a list of the number of appeals to medical institutions, reports of medical examinations; 3) disability determinants; 4) determinants of physical development such as somatometric (average height, weight, chest volume, geometric shape of organs and body tissues), somatotopic (geometry of the spine, legs, arms, skeletal development, etc.), and psychometric (arm strength, respiratory rate, blood pressure, etc.); 5) determinants of natural population movement (births, deaths, natural population growth, life expectancy). The authors noted that quantitative determinants mentioned above allowed determining in detail and systematically the level of health as an economic category. The findings showed that the global COVID-19 pandemic changes the legislation support of health care. Besides, the healthcare guarantees program ensures transparent government support in the medical sector of Ukraine. The authors indicated that using an «Analytical panels» (dashboards) service on the website of the National Health Service allowed the analytical data processing on medical costs. The authors highlighted the improvement in healthcare institutions' performance and financial transparency. The obtained results could be helpful for scientists and students interested in this research issue.

Keywords: health economics, economic category, bibliometric analysis, public policy, COVID-19 impact.

Cite as: Koibichuk, V., Jakubowska, A., Drozd, S., \& Sydorenko, A. (2021). An Overview of the Elemental and Functional Content of the Health Indicators System as an Economic Category. Health Economics and Management Review, 2, 8-14. http://doi.org/10.21272/hem.2021.2-01 
Introduction. The economy is to produce and distribute products and services satisfying society's needs. In turn, human resources and human potential are the basis of the social sphere. Indeed, health care is considered to be the most important area of the social sphere. It rests on the intangible benefits under quality care delivery supported legislatively. It stands to note that healthcare is crucial in reproducing, restoring the workforce, and effective economic functioning.

Health is an essential economic category. Undoubtedly, social development depends on the standard of health. Therefore, raising living standards requires a quality health care system.

Disease and injury clearance is one of the determinants of health. However, to recognize people as completely healthy, it is necessary to consider their spiritual integrity, psychological comfort (Rogowski, 2017). Therefore, social well-being is another determinant of health (Fundamentals of Ukrainian legislation on health care, 2021).

Health is the most important medical category while study normal and abnormal processes in the human body, looking for preventive measures, treat human diseases, and promote health. The actions determining health care are protecting, restoring, and supporting a person for the optimal social life level and capacity; ensuring a normal level of human physiology and psychological functions; fulfilling the maximum life expectancy (Fundamentals of Ukrainian legislation on health care, 2021; World Health Organization. Frequently Asked Questions, 2021). In turn, human capital is considered to be a systematized system for labor exploitation. Even though workers have a different state of health, completely healthy people are more competitive since they could work more productively. Therefore, they create additional value for the product. Based on the mentioned above, health investments of the labor force are the opportunity to restore human capital and boost the economy, country, and society.

Literature Review. In the study (Denysenko and Dolot, 2017), the authors described health regarding the economic relationship between man and state health care system. From the standpoint of economic potential, the government benefits from supporting the population's optimal physical and sociopsychological health. Indeed, a country cannot exist without human force, while people without healthcare. Therefore, health and the economy are interdependent.

The Western countries' experience shows the growth in health care budgets has a positive effect on economic development. Notably, life expectancy provides the growth of GDP per capita by $25-32 \%$. It stands to mention that it exceeds the amount spent on health care several times (Shipko et al., 2020; Biewendt, 2020).

In the paper (Folland et al., 2012), the researchers identified several reasons for state intervention in the health economy as follows 1) creating optimal levels of public goods consumption and production; 2 ) improving the quality and fairness of medical services in the private health sector; 3) avoiding the market monopoly; 4) increasing health care accessibility for people struggling with paying for private hospitals.

The analysis of scientific publications confirmed the relevance of the study the health economics as an economic category. This study involved the bibliometric analysis of 610 scientific publications indexed by the Scopus database from 2010 to May 2021. The obtained results showed the distribution of the articles by the countries. 


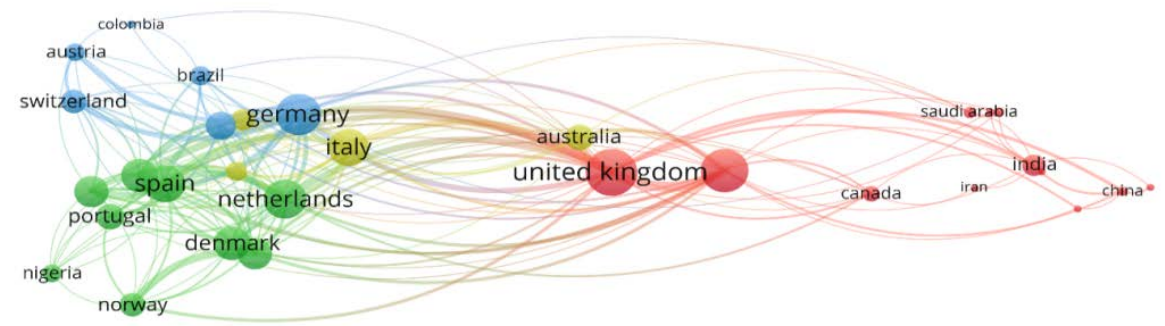

Figure 1. Visualization of investigated articles by the research areas

Sources: developed by the authors based on the Scopus database using VOSviewer 1.6.15 software.

Figure 2 demonstrates the distribution of investigated publications by the countries. It stands to mention that the United Kingdom was the most active in studying the health economy. The British researchers published 182 documents on the investigated issues. At the second stage, the researchers from Germany published 69 documents, from the USA - 66, Sweden -39.

\begin{tabular}{|c|c|c|c|c|}
\hline Selected & Country & Documents $\checkmark$ & Citations & $\begin{array}{l}\text { Total link } \\
\text { strength }\end{array}$ \\
\hline$\nabla$ & united kingdom & 182 & 1530 & 76 \\
\hline$\nabla$ & germany & 69 & 682 & 54 \\
\hline (v) & united states & 66 & 950 & 48 \\
\hline$\nabla$ & sweden & 39 & 652 & 39 \\
\hline$\nabla$ & china & 35 & 241 & 10 \\
\hline$\nabla$ & france & 32 & 410 & 26 \\
\hline (v) & spain & 29 & 362 & 53 \\
\hline$\nabla$ & india & 29 & 81 & 14 \\
\hline$\nabla$ & denmark & 21 & 223 & 31 \\
\hline 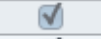 & netherlands & 19 & 328 & 53 \\
\hline$\nabla$ & italy & 19 & 307 & 43 \\
\hline$\checkmark$ & norway & 16 & 348 & 24 \\
\hline$\nabla$ & australia & 15 & 102 & 22 \\
\hline$\nabla$ & greece & 14 & 296 & 35 \\
\hline ( & switzerland & 12 & 327 & 22 \\
\hline$\nabla$ & canada & 11 & 275 & 11 \\
\hline$\nabla$ & turkey & 11 & 20 & 0 \\
\hline$\nabla$ & colombia & 10 & 61 & 4 \\
\hline$\nabla$ & austria & 9 & 77 & 14 \\
\hline$\sqrt{ }$ & brazil & 9 & 98 & 14 \\
\hline
\end{tabular}

Figure 2. The distribution of the publications indexed by the keyword "health economy» Sources: developed by the authors based on the Scopus database using VOSviewer 1.6.15 software.

On the other hand, Figure 3 demonstrates the list of keywords that determine health as the economic category. Thus, six main clusters indicate the research directions of analyzed publications. Thus, the health economy is investigated relating COVID-19, digitalization, cost-effectiveness, environmental burden, etc. 


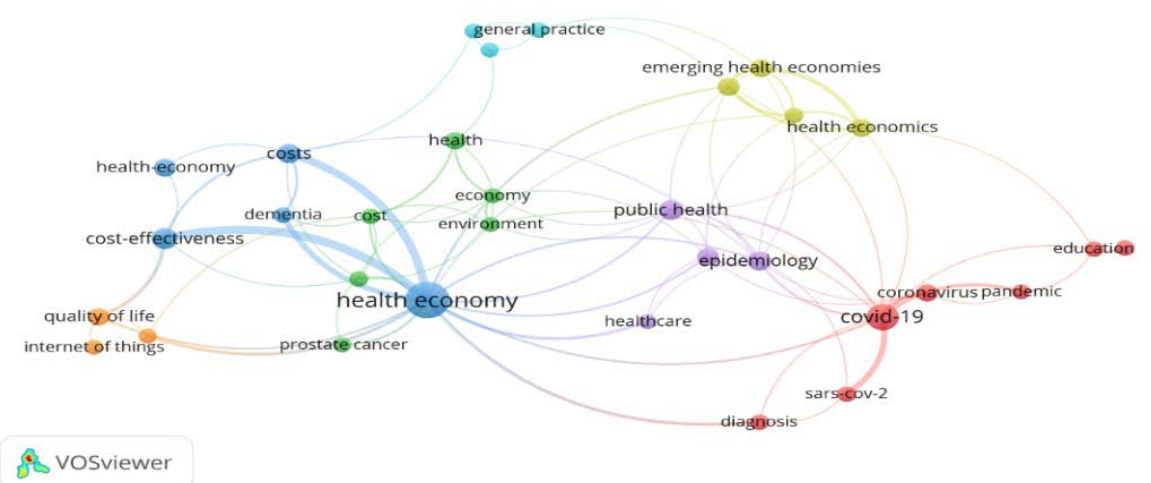

Figure 3. Determining the health economy as an economic category by the keywords Sources: developed by the authors based on the Scopus database using VOSviewer 1.6.15 software.

Methodology and research methods. For gaining the research goal on determining healthcare as the economic category, this study involved the semantic analysis techniques, the method of comparison, logical approach, bibliometric and structural analysis. The practical study realization was conducted using the VOSviewer 1.6.15 software tools.

Results. Health economics does not have a complete commodity form, while it has the highest consumer value. Indeed, health is the most expensive and invaluable human life capital, while it is impossible to sell or buy health in absolute terms (Probst et al., 2020; Shipko et al., 2020). However, it is possible to indirectly assess the costs of health measures, such as prevention, rehabilitation, and treatment, even though these metrics may not be relevant to finding a health price.

The findings of bibliometric analysis of presented publications (Bartkova et al., 2020; Hussain et al., 2020; Letunovska et al., 2020), and legislative documents analysis (Verkhovna Rada of Ukraine, 2021) in terms of health care indicates its complexity and multifacetedness since quantitative and qualitative indicators of the medical, socio-spiritual and political spheres (Kolomiiets and Petrushenko, 2017; Keliuotytè-Staniulènienè and Daunaravičiūtè, 2021; Yelnikova et al., 2020a).

Notably, in terms of typical medical and statistical indicators, five groups by factors were distinguished as follows. The first group comprises medical and demographic orientation indicators (such as population, sex, population, social groups). The second group is created with morbidity indicators, their composition, a list of the number of appeals to medical institutions, reports of medical examinations. The third group consists of disability indicators. They are formed from the absolute number of disabled people registered with the social protection authorities. The fourth group includes indicators of physical development such as somatometric (average height, weight, chest volume, geometric shape of organs and body tissues), somatotopic (geometry of the spine, legs, arms, skeletal development, etc.), and psychometric (arm strength, respiratory rate), blood pressure, etc.). The fifth group includes indicators of natural population movement (births, deaths, natural population growth, life expectancy). These comprehensive quantitative indicators allow determining in detail and systematically the level of integrated health as an economic category (Baydas et al., 2020; Dźwigoł, 2021).

In general, the number of factors influencing a person goes to infinity. Radical changes in health could happen in a day or 10 years. For example, according to the WHO, 13.7 deaths in 2016 (24\% of global deaths) were caused by various environmental risks. Therefore, it could be stated that approximately one in four deaths worldwide is caused by environmental conditions. 
V., Koibichuk, A., Jakubowska, S., Drozd, A., Sydorenko. An Overview of the Elemental and Functional Content of the Health Indicators System as an Economic Category

There are many pathogens and ways of spreading disease. Besides, general unhealthy environmental conditions provoke most diseases and injuries. It is worth mentioning that non-communicable diseases, including coronary heart disease, chronic respiratory disease, and cancer, are the most common consequences of global environmental changes (WHO, 2021a; Kashyap et al., 2020).

The findings on a bill systematization showed their main concern areas such as regulating the pharmaceuticals sale to children and persons under 14, regulating the circulation of cannabis, protecting the population from infectious diseases, protecting public health from harmful effects of tobacco, timely informing citizens (Fundamentals of Ukrainian legislation on health care, 2021). Notably, all of these bills are vital in improving people's lives during the COVID-19 pandemic.

The COVID-19 consequences are long-term in different spheres of human life, from world political changes, business (Boronos et al., 2020), insurance (Didenko and Sidelnyk, 2021; Yelnikova et al., 2020 b) to troubles at home (Dutta et al., 2020; Ray, 2021).

It stands to mention some political examples, such as the protests in Hong Kong and the loss of Donald Trump in the election race. The pandemic is considered to be the «Great Financial Crisis». It has already led to financial and geopolitical dysfunction. Most world economies have experienced serious problems. Thus, on 23 March 2020, the Secretary-General of the United Nations, Antonio Guterres, called for a global ceasefire as part of the UN response to the COVID-19 coronavirus pandemic. On 1 July 2020, the UN Security Council adopted United Nations Security Council Resolution 2532

UN Security Council Resolution 2532 claiming a general and immediate cessation of hostilities at all competing interests. Furthermore, it invoked the conflict parties to immediately put into cold storage for at least 90 consecutive days. In turn, it requires international cooperation to address the pandemic (Resolution, 2020).

Healthcare delivery is another health care area that was changed during the pandemic. Most health care providers have switched to providing virtual or telemedicine visits instead of traditional office visits. Many countries reported the rise of domestic violence and intimate partner violence during the COVID-19 restrictions. Financial instability and declining stress balance have significantly increased domestic violence. Indeed, people were not ready for close coordination with family while reducing outdoor social networking. Thus, the UN Secretary-General called for a «ceasefire» in domestic violence (UN News, 2020).

On the other hand, the findings showed that the COVID-19 pandemic was accompanied by suicidal ideation due to social isolation and social restrictions, fear, unemployment, and financial factors (Hinrichs and Bundtzen, 2020; The Lancet, 2020; Vasylieva et al., 2020).

Thus, 2020 year greatly changed society and the public health system. Besides, there were upheavals in financing medical institutions to provide the appropriate level of medical care (Kadar and Reicher, 2020). The healthcare system has become transparent and independent due to the Healthcare Guarantee Programme 2020. In turn, 1600 specialized medical institutions became partners of the National Health Service of Ukraine. These institutions received more than 100 billion UAH over 4 quarters. Anyone concerned can review medical services' analytical and reporting documents due to impersonal open data (National Health Service of Ukraine, 2021).

On 1 April 2021, the new expanded and detailed Healthcare Guarantees Program was launched. This program provides patients with more convenient and understandable services use. The Healthcare Guarantees Program provides 35 packages of medical services. The Program budget is 123.5 billion UAH in 2021. As of 28 May 2021, 48 billion UAH was paid under the medical guarantees program. Costs of the COVID-19 counteracting was 7 billion UAH (National Health Service of Ukraine, 2020).

Conclusions. This study presents the review of scientific publications devoted to healthcare as the economic category. The findings showed the qualitative and quantitative determinants of health. The public health policy was analyzed. The study described the COVID-19 impact on the government 
V., Koibichuk, A., Jakubowska, S., Drozd, A., Sydorenko. An Overview of the Elemental and Functional Content of the Health Indicators System as an Economic Category

apparatus and changes in the global political arena. The obtained results showed the systemic change in Ukrainian healthcare. Thus, the healthcare guarantees program established transparent government support to medical institutions to provide effective work performance. Besides, the Analytical Panel (dashboards) on the National Health Service website provides the analytical processing on the medical costs. Therefore, health and healthcare are interrelated with the socio-economic system. Therefore, health should be the main determinant of society and life quality.

Author Contributions: conceptualization, S. D.; methodology, V. K. and A. J.; software, S. D. and A. S.; validation, V. K. and S. D.; formal analysis, A. S. and A. J., investigation V. K.; resources, A. S.; data curation, S. D.; writing-original draft preparation, V. K.; writing-review and editing, V. K.; visualization, S. A.; supervision V. K. All authors have read and approved the final manuscript.

Funding: This research did not receive any funding.

\section{References}

Bartkova, L., Veselovska, L., Sramkova, M., \& Zavadsky, J. (2021). Dual Quality of Products: Myths and Facts through the Opinions of Millennial Consumers. Marketing and Management of Innovations, 1, 236-252. [Google Scholar] [CrossRef]

Baydas, A., Yalman, F., \& Bayat, M. (2021). Consumer Attitude Towards Organic Food: Determinants of Healthy Behaviour. Marketing and Management of Innovations, 1, 96-111. [Google Scholar] [CrossRef]

Biewendt, M. (2020). Sustainable Development: A Quantitative Analysis Regarding the Impact of Resource Rents on State Welfare from 2002 to 2017 . SocioEconomic Challenges, 4(4), 119-131. [Google Scholar] [CrossRef]

Boronos, V., Zakharkin, O., Zakharkina, L., \& Bilous, Y. (2020). The impact of the covid-19 pandemic on business activities in Ukraine. Health Economics and Management Review, 1(1), 76-83. [Google Scholar] [CrossRef]

Denysenko, M., \& Dolot V. (2017). Health as an economic category. Economics, 29-31. Retrieved from [Link]

Didenko, I., \& Sidelnyk, N. (2021). Society's Readiness for Modern Challenges of the Insurance Market: Bibliometric Analysis. Financial Markets, Institutions and Risks, 5(1), 116-125. [Google Scholar] [CrossRef]

Dutta, P., Dutta, U., Hasan, S., Sarkar, S., \& Sana, T. (2020). Educate, Empower And Protect People Through Timely Authentic Information: Explore How Bangladeshi Newspapers Response To COVID-19 Pandemic. SocioEconomic Challenges, 4(3), 93-103. [Google Scholar] [CrossRef]

Dźwigoł, H. (2021). Leadership in the Research: Determinants of Quality, Standards and Best Practices. Business Ethics and Leadership, 5(1), 45-56. [Google Scholar] [CrossRef]

Folland, S., Goodman, A. C., \& Stano, M. (2012). The Economics of Health and Health Care. Routledge Retrieved from [Link] Fundamentals of Ukrainian legislation on health care. (2021). Retrieved from [Link]

Hinrichs, G.,\& Bundtzen, H. (2021). Impact of COVID-19 on personal insurance sales - Evidence from Germany. Financial Markets, Institutions and Risks, 5(1), 80-86. [Google Scholar] [CrossRef]

Hussain, S. A., Haq, M. A. U., \& Soomro, Y. A. (2020). Factors Influencing Consumers' Green Purchase Behavior: Green Advertising as Moderator. Marketing and Management of Innovations, 4, 144-153. [Google Scholar] [CrossRef]

Kadar, B., \& Reicher, R. Zs. (2020). Innovations in Health Care Management: the Effect of the Pandemic on the Labour Market Change. Marketing and Management of Innovations, 4, 120-130. [Google Scholar] [CrossRef]

Kashyap, G. C., Puri, P., \& Singh, S. K. (2020). Respiratory Health Upshots due to Contaminated Living Environment: A Cross-

Sectional Study of the Industrial Belt of Kanpur City, India. SocioEconomic Challenges, 4(1), 17-27. [Google Scholar] [CrossRef] Keliuotytè-Staniulènienè, G., \& Daunaravičiütè, K. (2021). The Global Green Bond Market in the Face of the COVID-19 Pandemic. Financial Markets, Institutions and Risks, 5(1), 50-60. [Google Scholar] [CrossRef]

Kolomiiets, U., \& Petrushenko, Y. (2017). The human capital theory. Encouragement and criticism. SocioEconomic Challenges, 1,(1), 77-80. [Google Scholar] [CrossRef]

Letunovska, N., Kwilinski, A., \& Kaminska, B. (2020). Scientific Research In The Health Tourism Market: A Systematic Literature

Review. Health Economics and Management Review, 1(1), 8-19. [Google Scholar] [CrossRef]

National Health Service of Ukraine. (2020). Payments to providers of medical care under the program of medical guarantees

Retrieved from [Link]

National Health Service of Ukraine. (2021). The 2021 Medical Guarantees Program has been launched. Retrieved from [Link]

Probst, D. T., \& Kasztelnik, K. (2020). The Observational Research Study with the Trends in Healthcare Training and Leadership

Ethics in The United States. Business Ethics and Leadership, 4(3), 6-24. [Google Scholar] [CrossRef]

Ray, A. (2021). Containing Airborne Transmission of COVID-19 and Its Implications for Global Economic Recovery. Business Ethics and Leadership, 5(1), 81-88. [Google Scholar] [CrossRef]

Rogowski, R. (2017). Theoretical reasons for economic sociology. SocioEconomic Challenges 1 (4): 45-49. [Google Scholar] [CrossRef] 
V., Koibichuk, A., Jakubowska, S., Drozd, A., Sydorenko. An Overview of the Elemental and Functional Content of the Health Indicators System as an Economic Category

Shipko, A., Demikhova, N., Pajak, K., \& Motrechko, V. (2020). Health management at the regional level: multivariable performance assessment. Health Economics and Management Review, 1(2), 8-16. [Google Scholar] [CrossRef]

Shipko, A., Shklyar S., Demikhov, O., \& Dzwigol, H. (2020). Public health services: implementation of healthcare technologies. Health Economics and Management Review, 1(1), 84-92. [CrossRef]

The Lancet. (2020). Suicide risk and prevention during the COVID-19. Retrieved from [Link]

UN News. (2020). UN chief calls for domestic violence 'ceasefire' amid 'horrifying global surge'. Retrieved from [Link]

United Nations. (2020). Resolution 2532. Retrieved from [Link]

Vasylieva, T., Kuzmenko, O., Rashid, M. N., Vojtovic, S., Kascha, M., \& Lieonov, H. (2020). Innovations in government management of the healthcare system: forecasting of covid-19 consequences in social, investment and business development. Marketing and Management of Innovations, 4, 11-25. [Google Scholar] [CrossRef]

Verkhovna Rada of Ukraine. (2021). Legislative activity in the committees of the Verkhovna Rada of Ukraine Committee on Health of the Nation, Medical Care and Medical Insurance. Retrieved from [Link]

WHO. (2021a). Environmental protection. Retrieved from [Link

WHO. (2021b). Frequently Asked Questions. Retrieved from [Link]

Yelnikova, J., \& Kwilinski, A. (2020a). Impact-Investing in The Healthcare in Terms of the New Socially Responsible State Investment Policy. Business Ethics and Leadership, 4(3), 57-64. [Google Scholar] [CrossRef]

Yelnikova, Y., \& Golochalova, I. (2020b). Social Bonds as an Instrument of Responsible Investment. Financial Markets, Institutions and Risks, 4(4), 119-128. [Google Scholar] [CrossRef

Віталія Койбічук, Ph.D, доцент, Сумський державний університет, Україна

Агнєшка Якубовська, Кошалінський технологічний університет, Польща

Сергій Дрозд, Сумський державний університет, Україна

Анастасія Сидоренко, Сумський державний університет, Україна

Огляд елементно-функціонального змісту системи показників здоров'я як економічної категорії

Ця стаття узагальнює аргументи та контраргументи в межах наукової дискусії щодо визначення сутності здоров'я як економічної категорії. Результати систематизації наукових джерел та підходів до дослідження означеної проблематики засвідчили існування розривів у наукових напрацюваннях, щодо чіткого формування та детального опису визначальних детермінант здоров'я як економічної категорії. Для досягнення поставленої мети, дослідження здійснено в наступній логічній послідовності: 1) визначення загальної проблематики; 2) теоретичний аналіз поняття здоров'я як економічної категорії; 3) класифікація детермінант здоров'я; 4) визначення напрямків діяльності державної політики щодо означеної проблематики; 5) визначення глобальних змін через пандемію COVID-19. Методологія даного дослідження заснована на методах систематизації, порівняння, структурного аналізу, логічного узагальнення та бібліометричного аналізу. Для візуалізації результатів застосовано інструментарій програмного забезпечення VOSviewer 1.6.15. Вихідними даними для бібліометричного аналізу є 610 статей, представлених у наукометричній базі даних Scopus у період з 2010 року по травень 2021 року. У роботі було класифіковано детермінанти здоров'я за елементно-функціональним змістом: 1) показники медикодемографічного спрямування (чисельність населення, стать, склад населення, соціальні групи); 2) показники захворюваності, склад та перелік яких формується на основі кількості звернень до медичних закладів, звітів з медичних оглядів; 3) показники інвалідності, зареєстровані в органах соціального захисту населення; 4) показники фізичного розвитку населення (соматометричні, стоматоскопічні та фізіометричні); 5) показники природного руху населення (народжуваність, смертність, природний приріст населення, середня тривалість життя). Зазначені вище комплексні показники дозволяють детально та систематизовано визначити рівень інтегрального показника здоров'я як економічної категорії. У ході дослідження проаналізовано зміни законодавчих документів, щодо державної підтримки охорони здоров'я. Авторами оцінено вплив глобальної пандемії COVID-19 на медичну сфферу. Описано системні зміни у медичній сфері України у результаті функціонування програми медичних гарантій, яка передбачає прозору державну підтримку медичних закладів та забезпечує аналітичні дані щодо медичних витрат за допомогою сервісу «Аналітичних панелей» (дашбордів), що представлений на сайті Національної служби здоров'я. За результатами дослідження, автори прийшли до висновку щодо покращення роботи медичних закладів та забезпечення фінансової прозорості. Отримані результати мають практичну цінність та можуть бути корисними науковцям та студентам, які зацікавлені у дослідженні питань економіки здоров'я.

Ключові слова: економіка здоров'я, економічна категорія, бібліометричний аналіз, державна політика, вплив COVID-19. 